\title{
Assessing records management in municipalities with adverse audit opinions in Limpopo Province, South Africa
}

\author{
Lefose Makgahlela \\ University of Limpopo \\ University of KwaZulu-Natal \\ lefose.makgahlela@ul.ac.za \\ http://orcid.org/0000-0003-1433-2527
}

Received: 11 August 2020

Revised: 21 April 2021

Accepted: 28 August 2021

\author{
Zawedde Nsibirwa \\ University of KwaZulu-Natal \\ nsibirwaz@ukzn.ac.za \\ http://orcid.org/0000-0001-8527-1560
}

\begin{abstract}
This article assesses records management in municipalities with adverse audit opinions in the Limpopo province, South Africa. Audit reports issued by the Auditor-General of South Africa (AGSA) yearly indicate that poor recordkeeping is one of the factors contributing to adverse audit opinions in the public sector. The high level of corruption and maladministration, and lack of accountability and transparency in municipalities have become endemic and are a cause for concern in South Africa. Access to relevant and comprehensive information from records is essential for municipalities to perform their constitutional duties effectively. For this study, a quantitative research approach was employed using the survey design. Six municipalities in Limpopo that had adverse audit outcomes in the auditor-general's report of 2015/2016 were targeted. A total of 92 questionnaires were distributed to registry staff employed in the municipalities and 86 of these were completed and returned. Findings revealed that the selected municipalities in the province face numerous challenges relating to records management practices, including staff shortages, lack of training and poor storage facilities. The study recommends that municipalities' management and political office-bearers take all the necessary steps to prioritise records management by employing more people. The study further recommends that more universities in South Africa should provide formal qualifications in records management, and government officials should make funding available for records management practices.
\end{abstract}

Keywords: Records management, municipalities, local government, Limpopo Province

\section{Introduction}

The issue of records management practices in the municipalities of South Africa, Africa and worldwide has attracted scholarly attention for a long time (Ngoepe \& Van der Walt 2010; Ngoepe 2012; Bakare \& Issa 2016; Abuki 2014; Nevhutalu 2016). Recently, this issue continues to attract interest, particularly in light of the records management supporting the audit process in municipalities. Although some researchers like Ngoepe (2012), Abuki (2014), Marutha (2016), Bakare and Issa (2016), and Nevhutalu (2016) paid attention to records management, the need for all organisations, including municipalities, to keep proper records 
cannot be overemphasised. Through their daily activities, municipalities generate large volumes of records and, like other government entities, they are legally bound to systematically retain and preserve records and adhere to existing policies and procedures. Records exist as recorded information in either physical or electronic formats and are created, received and processed by organisations during business. Any government entity or any other institution effectively performing its mandate depends on the availability of relevant and comprehensive information drawn from records. In acknowledging the importance of sound records management practices in the public sector, the Parliament of the Republic of South Africa passed the National Archives and Records Services Act (No. 43 of 1996) to regulate records management functions in government entities.

However, 17 years ago, Venter (2004: 1) reported that recordkeeping in government departments had declined to the point where it was severely hampering government business conduct and undermining necessary public accountability. Mosweu and Rakemane (2020: 116) assert that poor records management practices still undermine the governance process in many African countries, and governance remains a matter of grave concern among African citizens. Furthermore, poor records management is guaranteed to result in information gaps, leading to incomplete records and loss of documentary heritage (Wamukoya \& Mutula, 2005). Given the above, it seems that if public records are not adequately managed, there will be a loss of the national documentary heritage and an inevitable maladministration of government information. The ability of the public sector to effectively carry out its constitutional mandate depends largely on the availability of relevant and comprehensive information from records. When there are poor records management practices in public sectors such as municipalities, information about the activities of the public sector is hard to find. While South Africa has developed legislation and policies guiding public and private institutions in managing records, municipalities face challenges in managing records for budgeting and planning for service delivery. These challenges hamper sound records management practices in these municipalities.

\section{Statement of the problem}

Efficient records management is essential to protect the rule of law, improve quality service delivery and demonstrate equal treatment of communities. Although the South African government recognises the importance of records management practices in the public sector, there is accord among researchers that records management in the sector is neglected (Makhura 2001; Venter 2004; Kanzi 2010; Ngoepe 2012; Nevhutalu 2016). Moreover, there is a persistent concern that there can be no rule of law, service delivery, accountability and transparency without effective records management in the public sector. Municipalities, in particular, face challenges of improving and promoting sound records management practices to deliver on their constitutional and legislative mandate. Despite numerous benefits of effective records management, recordkeeping in the public sector declined to the point where it is severely hampering the conduct of municipal administration, government business and undermining necessary accountability to the public (Venter 2004: 1). This is confirmed by the global corruption barometer, Transparency International (2020), which rates public sector corruption in 180 countries. South Africa scored 45\% in 2016 and declined to $43 \%$ in 2018. The country is currently (2020) ranked 69 at $44 \%$. 
Good records management practices are essential in all municipalities. Despite the legislation and policies regulating records management in municipalities being in place, there seems to be ignorance concerning records management in Limpopo municipalities and neglect of records management (Makhura 2001; Kanzi 2010; Nevhutalu 2016). While the neglect of records management is evident, the challenges that records managers in municipalities face in managing records are still unclear. Consequently, this study sought to assess records management in municipalities with adverse audit opinions in selected municipalities in Limpopo. The study was motivated by concerns that municipalities in South Africa face challenges in improving and promoting sound records management practices to deliver on their constitutional and legislative mandate. The auditor-general's (AG) audit report on South African municipalities for the 2014-15 financial year revealed that municipal audit outcomes in Limpopo had been disappointing and records management was an aspect that resulted in poor audit outcomes. Ngoepe (2012) attests that records management programmes in many government departments were wavering on the brink of collapse.

Therefore, the aim of this article is to answer the following research questions:

1) What are the challenges of records management in the selected municipalities of the Limpopo province?

2) How knowledgeable are staff in the municipalities about records management practices?

\section{Literature review}

This review of related literature discusses the factors affecting records management practices in organisations. This is followed by examining the knowledge and skills of municipal staff regarding records management practices and, finally, the challenges faced specifically in managing records in municipalities are outlined.

\subsection{Factors that affect records management practices in organisations}

Various factors contribute to and affect records management practices in organisations. The International Records Management Trust (IRMT) (2012) reported that some of the contributing factors to the current records management practices in the East and Southern African Regional Branch of the International Council on Archives (ESARBICA) region were:

... the absence of organisational plans for managing records; low awareness of the role of records management in support of organisational efficiency and accountability; lack of stewardship and coordination in handling records; and absence of legislation, policies and procedures to guide the management of records.

The concerns surrounding records management practices in organisations are essentially the absence of policies and procedures. For example, Chinyemba and Ngulube's (2005) study of records management at the University of KwaZulu-Natal (UKZN) revealed poor and inadequate policies for managing records, which contributed to the deplorable state of records management in this institution of higher learning. Ndenje-Sichalwe (2010) found the main factor contributing to poor records management practices in Tanzania related to inadequately trained registry staff. In a similar vein, a study conducted by the IRMT (2012) of the ESARBICA region revealed lack of fundamental competencies in records management, lack of sufficient financial resources devoted to records management and absence of migration 
strategies for records as factors contributing to current records management practices. In addition, Erima and Wamukoya (2012: 37) state that some factors contributing to records management at the Moi University in Kenya were "the absence of a records management programme to guide records management activities in the institution, lack of adequately trained records management staff, and changing technologies and data security, among others."

It can be concluded that numerous factors affect records management practices in organisations, including that strategies must be put in place to deal with these factors. An important factor in records management practices is senior management support (or absence of support) for records management. According to Zwikael (2008), top management backing has significantly on project accomplishment. A study by Ngoepe and Van der Walt (2009) established that factors contributing to unsatisfactory records management practices in South Africa were the paucity of records management policies in government departments, lack of top management support, lack of awareness of the importance of records management and lack of relevant skills among records management practitioners. Adu (2014) opines that senior management should embrace the records management function to ensure its effectiveness and to incorporate it into their performance management targets.

Funding is vital to accomplishing any organisational programme, including records management. In practice, limited financial resources for records management programmes sometimes mean a programme is impractical. Shepherd and Yeo (2003) report that financial resources are a requirement for a successful records management service. Staff with specialised skills, storage and equipment are needed, and these must be identified and are costed. Similarly, Mnjama and Wamukoya (2007) opine that a critical issue confronting ESARBICA countries in recordkeeping is the absence or insufficient allocation of financial resources for records management programmes. Therefore, funding or increased funding of records management programmes could immediately improve records management practices. For municipalities to develop effective and sustainable records management programmes, there should be precise funding arrangements.

\subsection{Records management knowledge and skills}

With many records created every day, it is vital for staff to be able to deal with these records. This can only happen if they have the required knowledge and skills to manage records. Staff training an essential step in implementing successful records management practices in municipalities. Thus, for proper records management practices to take place, staff involved in records management must be well trained (McLeod, Hare \& Johare, 2004). The World Bank (2000: 2) reported decades ago that "in many countries around the world, record-keeping systems are unable to cope with the growing mass of records, and this is particularly true in countries where records managers lack training or professional development opportunities." Marutha (2016:252) argues that "lack of skills and knowledge for records and archive management is still a greater challenge in Africa." Without qualified staff or effective training of staff, municipalities will never see the benefits of records management practices.

Proper records management is essential if municipalities are to be efficiently run. However, this can only be achieved if municipalities employ knowledgeable people with the requisite skills. According to Kanzi (2010: 56), "the training of staff who deal with the management of 
records is crucial to maintaining sound records management practices." Ngoepe (2016: 340) agrees that "implementing sound records management practices is a long and arduous journey that requires a combination of elements such as skilled people, resources, finance and mapped processes." However, Marutha (2016:252) revealed most employees in most healthcare institutions in the Limpopo were not knowledgeable and skilled for all records management operational and functional requirements and this was the reason for poor records management practices in healthcare institutions. Therefore, successful recordkeeping practices require welltrained registry clerks and records managers to face the growing number of records created daily. Through appropriate training, registry staff and records managers can expand their municipalities' current records management practices. According to Chinyemba and Ngulube (2005), in many African countries, human resources with appropriate skills, competencies and attitudes are not readily available to initiate, implement and sustain the digitisation project.

Another factor contributing to the current records management practices in South Africa and directly related to the lack of training and skills in records management, is the shortage of formally trained archivists and records managers (Keakopa 2007). This shortage is because few universities and other training providers offer formal training in records management. In South Africa, universities offering training in records management and archival studies include the University of South Africa, UKZN, University of Zululand and University of Fort Hare. Although an institution can have good records management policies and procedures, records management practices will remain largely ineffective without formally qualified records managers. The importance of qualifications is evinced in Katuu's (2009) study which found education, training and research could assist records managers and archival staff to deal with the challenges of poor records management practices in municipalities in Africa. Similar findings were noted in Botswana, Tanzania and Namibia (Nengomasha, 2013). A study in Nigeria by Iwhiwhu (2005) revealed that records managers are employed without considering the principles of records management and such managers have no idea or consciousness of the need to create and manage records with the utmost of care due to their lack of formal training.

\subsection{Challenges of records management practices}

Records management practices in most South African municipalities have been experiencing several challenges. These challenges impacted negatively on the municipalities' ability to execute and deliver on their constitutional mandates. While these encounters will differ from one municipality to another, the literature on the subject often highlights that the government sector, in general, faces severe challenges in managing records. According to the South African Local Government Association (SALGA) (2015), municipalities in South Africa face various challenges around records management. It is because of these challenges that Masimba (2014:128) points out that it "is no secret that the South African public sector is inefficient and there are pockets of excellence here and there, but it is plausible to say that generally, the public sector is inefficient".

Ngoepe and Ngulube (2014) state that most managers in the public sector do not view the organisation of records as one of their main concerns. If managers do not take records management seriously, there can never be proper records management and municipalities in South Africa will continue to face the challenge of improving and promoting sound records management practices to deliver on their constitutional and legislative mandates. 
Municipalities, like other government departments in South Africa, are experiencing growth and replication of records. Despite this, and as reported by SALGA (2015), one of the biggest challenges is that municipalities do not see records management as a critical business issue and there is a lack of discipline in adhering to records management processes. Furthermore, the SALGA (2015) posits that political and administrative leadership in local government is not making the importance of adhering to the records management processes clear.

Most African states are still lagging in technological and telecommunications infrastructure. According to Ngoepe and Van der Walt (2009), challenges of records management in government include lack of proper planning for records management and the absence of records management toolkits. Kanzi (2010), who conducted a study on the role of records management at the Amathole District Municipality, revealed there was ignorance regarding the management of records among municipal staff. A big challenge identified in Kanzi's (2010) study was records management not being incorporated in the organisation-wide strategic plans and key performance areas of senior managers.

In a study on records management challenges encountered in local government, SchellnackKelly (2013) found that while many municipalities have records management policies, they were not followed. Furthermore, Masimba (2014) reports that in the public sector, records are not valued due to a lack of priority attached to necessary administrative activities, which resulted in the neglect of records management. Masimba (2014) believes that the challenges faced by the National Archives and Records Service of South Africa (NARSSA) indicate a lack of funding and appear to be symptomatic of a disregard for the value and importance of records management in the public sector.

In a study of Nevhutalu (2016) on the state of records management practices in the South African public sector, with specific reference to Vhembe District Municipality, found the challenges faced by government departments were not unique to municipalities. These challenges included old infrastructure, few people with relevant skills in records management, inadequate training of staff, absence of understanding of records management functions and poor leadership. A related study conducted in Zimbabwe by Chaterera (2016: 166), found that a significant challenge faced by the government was that records management was not perceived as a significant component of corporate governance. Chaterera (2016) indicates that records management was an overlooked function playing no part in government administration.

A study of Katekwe and Mutsagondo (2018: 405) on "the challenges and prospects of records maintenance in public departments in Zimbabwe" revealed that Zimbabwe faced challenges related to the maintenance of records, inappropriately adapted buildings housing records, poor and inadequate filing equipment, skills and manpower. It is thus apparent that municipalities both in and outside South Africa still face challenges in managing records. Given these challenges, it will be difficult for these municipalities to improve their audit opinions.

\section{Research methodology}

Six Limpopo municipalities were selected using purposive sampling. These municipalities were relevant to the study because they had received adverse audit opinions in the AG's Municipal Audit Report of 2015/2016. The population was also purposively selected to include 
only staff who dealt with the management and care of records. The study used a mainly quantitative survey design. Data was collected using questionnaires. The choice of the research design guided the research questions in terms of data needed and how the data were collected and analysed. The SPSS statistical package was used to analyse the data and generate percentages, frequency bar charts and cross-tabulations.

\section{Results and discussion of findings}

Findings from the results of the survey of registry staff are presented and discussed. A total of 92 questionnaires were distributed to registry staff in six selected municipalities in Limpopo. Of these, 86 were returned, giving a response rate of 93\%. Babbie and Mouton (2001) state that a response rate of over $50 \%$ is satisfactory for data analysis and reporting, a response rate of $60 \%$ is good, and a response rate of $70 \%$ or more is excellent. The excellent response rate achieved in the study was a result of persistent follow-ups by the researchers.

\subsection{Demographic profiles}

To understand the nature of the respondents, their demographic profiles were elicited and the characteristics determined were:

1) Gender and age

2) Current job title and number of years in the current position

Findings relating to respondents' highest level of education are provided below.

\subsubsection{Gender and age}

It was essential to know the gender and age of the respondents to allow the researchers to establish which gender and age were involved in records management practices in the municipalities. The findings regarding gender and age are reflected in Table 1 below.

Table 1: Gender and Age $n=86$

\begin{tabular}{|l|l|l|l|l|l|l|}
\hline \multirow{2}{*}{ Age } & \multicolumn{5}{c|}{ Gender } & \multicolumn{2}{c|}{ Total } \\
\cline { 2 - 7 } & \multicolumn{2}{|c|}{ Male } & \multicolumn{2}{c|}{ Female } & \multicolumn{2}{c|}{ \% } \\
\cline { 2 - 7 } & Frequency & Frequency & $\%$ & Frequency & \% \\
\hline $\begin{array}{l}26-30 \\
\text { Years }\end{array}$ & 18 & 20.9 & 2 & 2.3 & 20 & 23.3 \\
\hline $\begin{array}{l}31-35 \\
\text { Years }\end{array}$ & 21 & 24.4 & 2 & 2.3 & 23 & 26.7 \\
\hline $\begin{array}{l}36-40 \\
\text { Years }\end{array}$ & 1 & 1.2 & 20 & 23.3 & 21 & 24.4 \\
\hline $\begin{array}{l}41 \quad \text { Years } \\
\text { and above }\end{array}$ & 19 & 22.1 & 3 & 3.5 & 22 & 25.6 \\
\hline Total & 59 & 68.6 & 27 & 31.4 & 86 & 100 \\
\hline
\end{tabular}

Most respondents (59: 68.6\%) were male and 27 (31.4\%) were female. Thus, there were more males than females working in the registry offices of the six selected municipalities. No age 
group dominated. However, the age group with the most respondents was 31-35 years with 23 (26.7\%), while the age group with the least respondents was 26-30 years with $20(23.3 \%)$. Twenty-three (26.7\%) were within the age group 31-35 years, 21 (24.4\%) were within the age group 36-40 years, and $22(25.6 \%)$ were 41 years and above.

\subsubsection{Current job title and years of working experience}

The respondents were asked to specify their current job titles. The researcher also solicited information on the number of years' work experience of the respondents in their current positions. Table 2 below presents the results.

Table 2: Job title and number of years in the position $n=86$

\begin{tabular}{|c|c|c|c|c|c|}
\hline \multirow{2}{*}{$\begin{array}{l}\text { Number } \\
\text { of years } \\
\text { in } \\
\text { current } \\
\text { position }\end{array}$} & \multicolumn{4}{|c|}{ Job title } & \multirow{2}{*}{$\begin{array}{c}\text { Total } \\
\text { Percentage }\end{array}$} \\
\hline & $\begin{array}{l}\text { Admin } \\
\text { Officer }\end{array}$ & $\begin{array}{c}\text { Senior registry } \\
\text { clerk }\end{array}$ & $\begin{array}{l}\text { Registry } \\
\text { clerk }\end{array}$ & $\begin{array}{l}\text { Record } \\
\text { officer }\end{array}$ & \\
\hline 1-3 Years & 0 & 0 & 12 & 0 & 14.0 \\
\hline 4-6 Years & 0 & 19 & 26 & 0 & 52.3 \\
\hline 7-9 Years & 1 & 0 & 3 & 0 & 4.7 \\
\hline $\begin{array}{l}10-12 \\
\text { Years }\end{array}$ & 21 & 1 & 0 & 0 & 25.6 \\
\hline $\begin{array}{l}12 \text { Years } \\
\text { and above }\end{array}$ & 2 & 0 & 0 & 1 & 3.4 \\
\hline Total & 24 & 20 & 41 & 1 & 100 \\
\hline
\end{tabular}

The results presented in Table 2 above reveal that most respondents (61: 71\%) were either registry clerks or senior registry clerks. This was followed by $24(27.9 \%)$ respondents who were administration officers. One (1.2\%) of the respondents was a records officer. Furthermore, $45(52.3 \%)$ respondents had been in their positions for 4-6 years, while 22 (25.6\%) indicated they had 10-12 years' working experience. Those with the least experience (1-3 years) numbered $12(14 \%)$. Overall, the findings revealed that most people working in the registry offices of the selected municipalities did not have many years' work experience.

\subsection{Factors that affect current records management practices}

While the study aimed to establish records management challenges in municipalities, it was important to understand the factors contributing to the present state of records management practices in the selected municipalities. Of particular importance to the study was Ngulube's (2003) contention that research in records management practices can improve understanding of factors contributing to current recordkeeping practices. Kanzi (2010) identified not using a file plan, lack of training of both records office staff and users, unqualified and demoralised records officers, and lack of support from senior management as factors that contribute to poor 
records management practices. To determine the factors contributing to the current state of records management practices in the municipalities, respondents were provided with a list of six factors (including an "other" category) and asked to indicate which one they considered as the main contributing factor. As reflected in Figure 1, most respondents (53:61.6\%) indicated that the shortage of staff was the main contributing factor to the current records management practices in the municipalities. This was followed by $21(24.4 \%)$ respondents who indicated insufficient funding as the main contributing factor. Finally, poor records management was mentioned as a factor by $10(11.6 \%)$ respondents and a lack of storage by two (2\%) respondents.
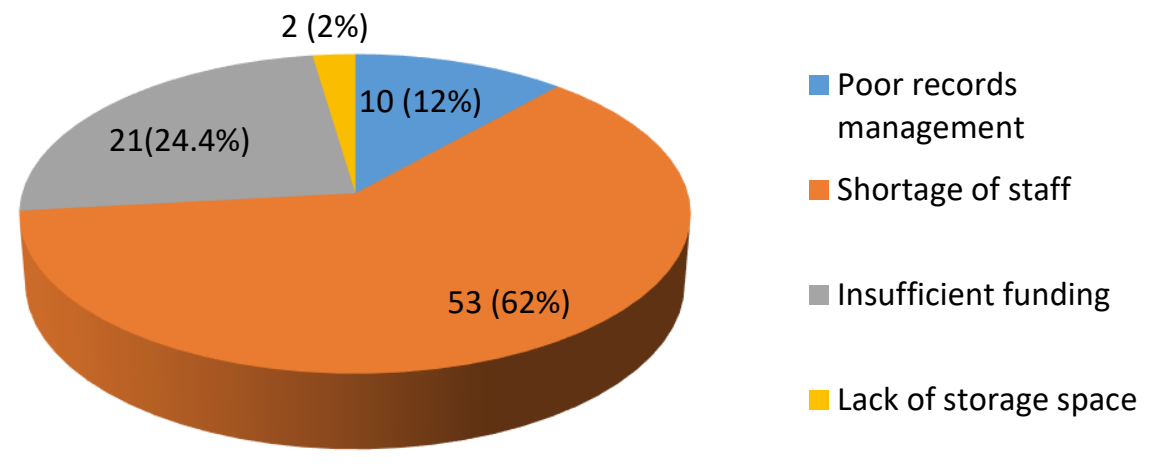

Figure 1: Factors contributing to the current records management practices $(n=86)$

\subsubsection{Types of records created}

Records management is a process of ensuring proper creation, maintenance, use and disposal of records. The importance of records creation in records management practices cannot be underestimated. Different types of records can bring various challenges to records management officials. According to NARSSA (2006), records creation is one of the key phases in the records life cycle. Literature reveals that if records are to meet the requirements of accountability and transparency, they must be managed appropriately from creation to disposition (Wamukoya, 2000). This is in line with NARSSA's (2006) provision that records must be adequately managed from creation to disposition to ensure their continuous availability. To understand the types of records created in municipalities, the respondents were asked about the main types of records created. Just over half (46: 53.5\%) of the registry officials stated that records created by their municipalities were mainly paper based. In comparison, 39 (45.3\%) mentioned electronic records as the primary type created. 


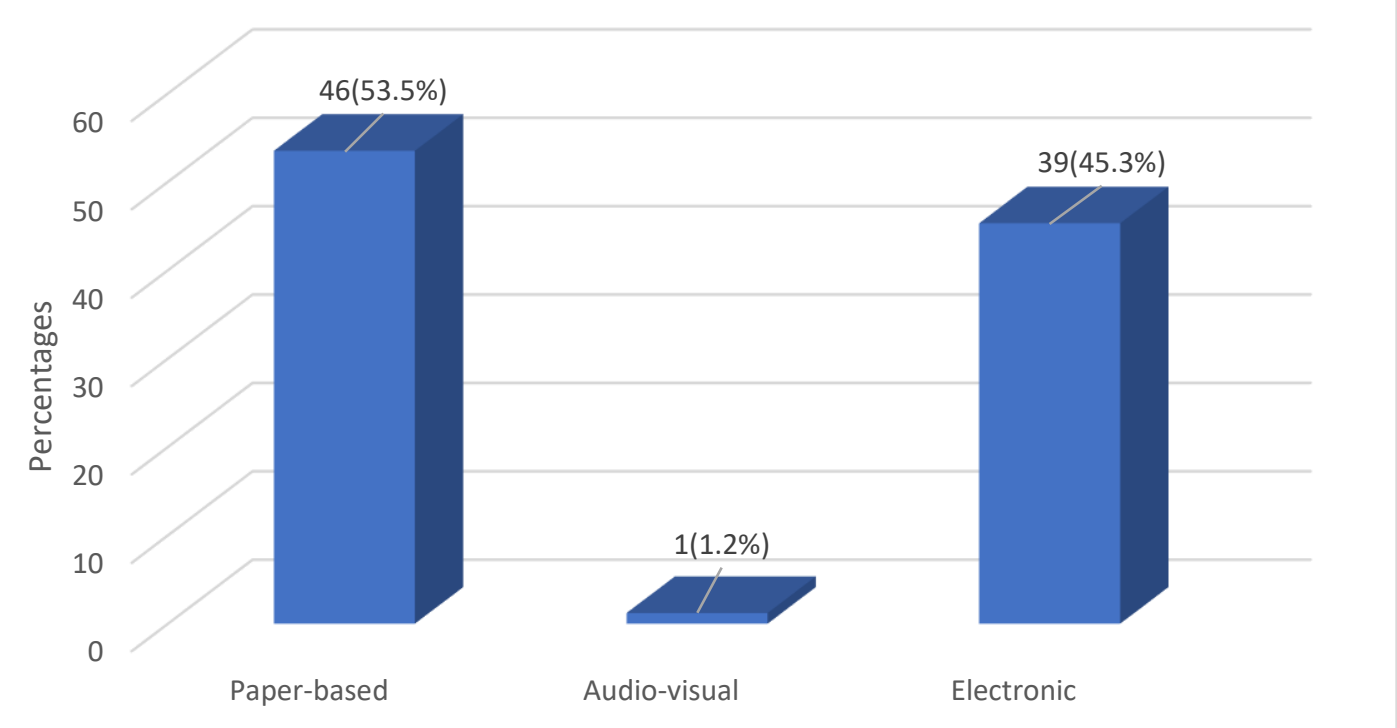

Figure 2: Types of records created $(\mathrm{n}=86)$

Given that Limpopo is a rural province with less technology, poor telecommunication infrastructure and a high level of illiteracy, it is not surprising that paper-based records are the main types of records created. Ndenje-Sichalwe (2010) corroborates these findings that "most of the records in the government ministries in Tanzania were created and maintained in the paper format". Furthermore, the IRMT (2012) found that "most government departments still depend on paper-based records to support most of their daily tasks". Similarly, a study by Bakare and Issa (2014) on the "assessment of records management practice in selected local government Councils in Ogun State, Nigeria" also established that there was a prevalence of paper as the medium for recording and conveying information in the selected local government councils. While municipalities still use paper based records and have limited technology with high levels of computer illiteracy Phiri (2016) states that electronic records are becoming the predominant format in South African universities. Universities are moving to electronic records and advancing technologically as the majority of university employees are computer literate. The results are presented in Figure 1.2 below.

\subsubsection{Filing of records}

When done correctly, the filing of records ensures the accurate and prompt retrieval of records when required. Records must be filed as soon as possible after receipt or creation. Failure to file records timeously can lead to many challenges. Sound records management practices ensure that records are correctly filed and stored. Every new record should be registered and maintained in a filing system with a reference number. Registry staff were asked to indicate how records are filed. As indicated in Figure 3 below, a small majority of registry staff (44: $51.2 \%)$ file their records alphabetically, while $38(44.2 \%)$ indicated they file their records alphanumerically. Only four $(4.7 \%)$ respondents stated that their records are filed numerically. Records in records storage areas must be filed according to the file plan and disposal schedule and should display the correct reference numbers. Given the low number of respondents under the impression that their municipality or municipalities file records numerically, MathebeniBokwe (2015) states that records in the Victoria Public Hospital in the Eastern Cape Province were filed numerically. 


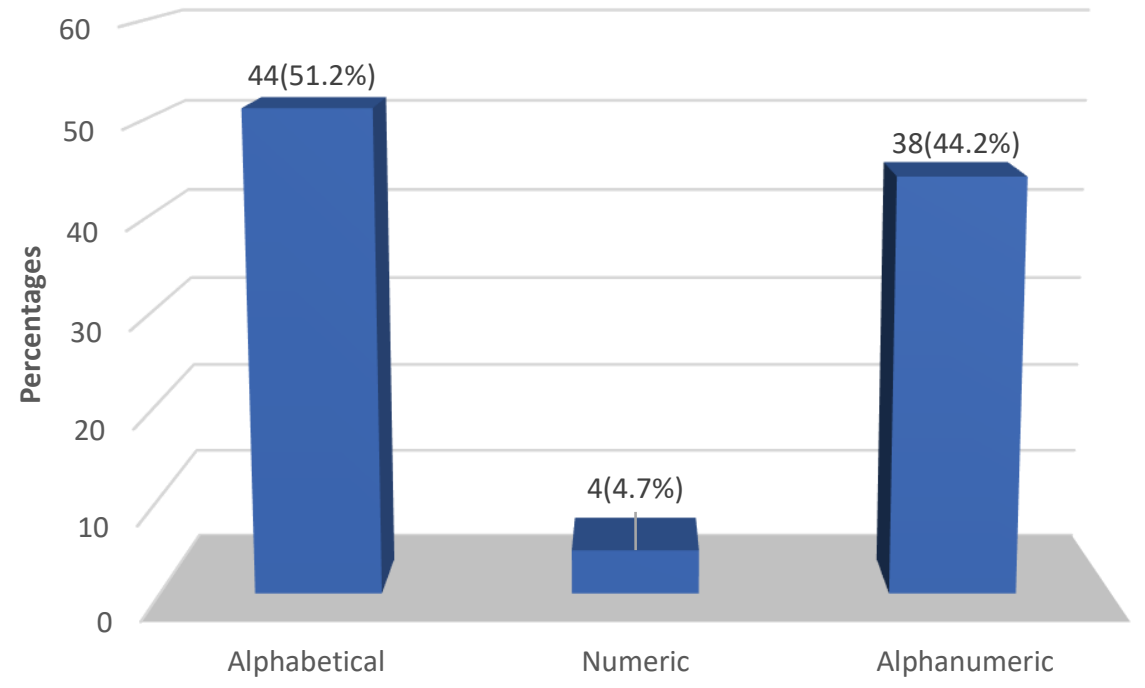

Figure 3: Records filing system $(\mathrm{n}=86)$

\subsection{Knowledge of staff in municipalities about records management practices}

Knowledge and skills play a crucial part in records management practices as they affect how records are created, used and disposed of. Therefore, qualified staff with relevant skills and knowledge are critical to successfully implement good records management practices. According to Popoola (2009), "the success of any organisation's records management practices depends on the skills, capability and level of commitment of the records personnel, who are indispensable to the system and an important force in the development of the organisation". Several questions were asked relating to knowledge and skills, namely respondents' highest level of education, formal qualifications in records management, and in-house training in records management.

\subsubsection{Highest level of education}

Education and training play an important role in ensuring staff efficiently comprehend and apply policies and good records management practices. Therefore, the respondents were requested to specify their highest level of education (see Figure 4). 


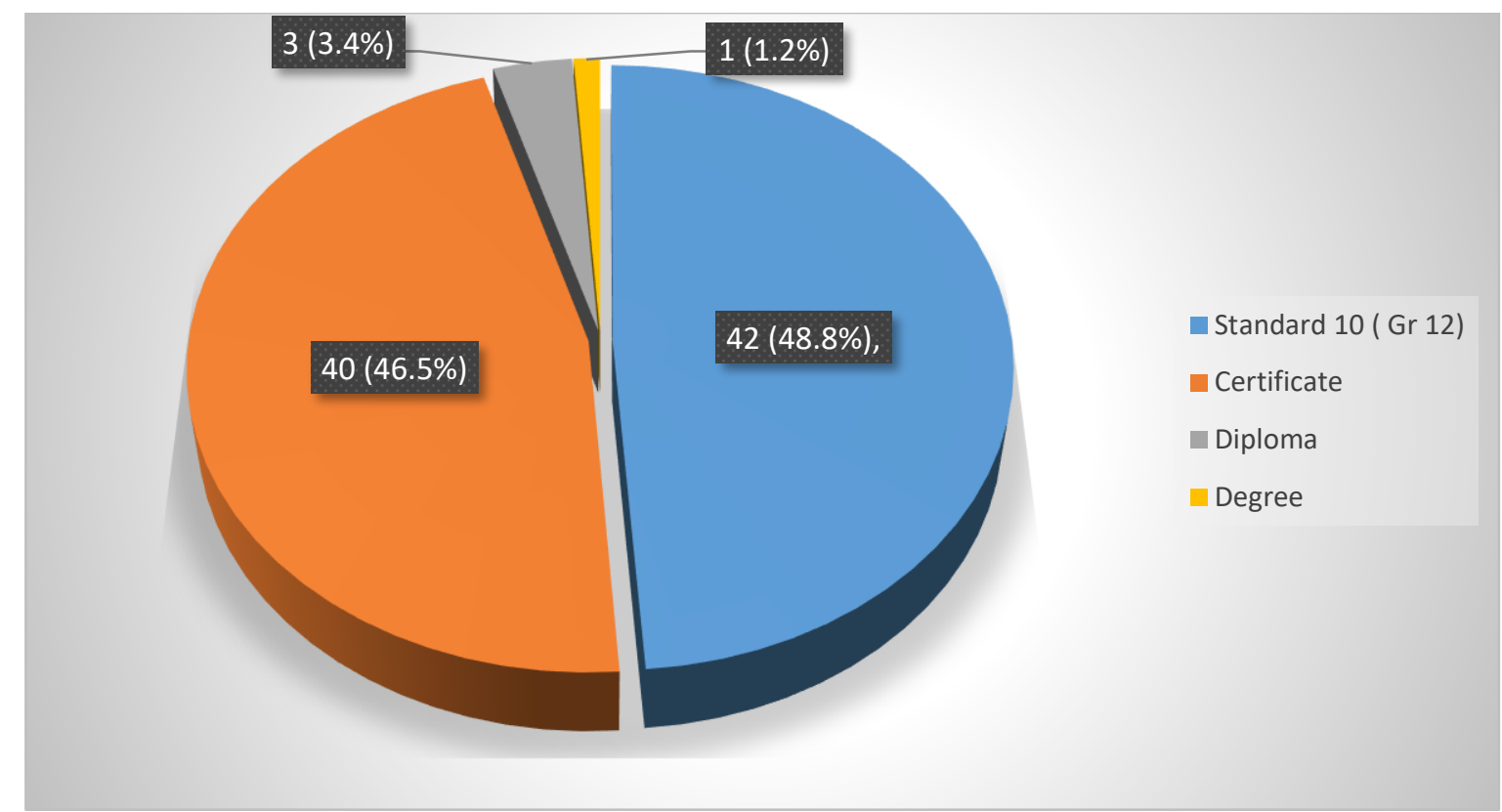

Figure 4: Highest level of education $(n=86)$

Most of the respondents (42: 48.8\%) had standard 10 (grade 12), followed by 40 (46.5\%) who had certificates. Three (3.4\%) respondents held diploma qualifications and only one $(1.2 \%)$ had a degree. This reiterates Marutha's (2016: 252) finding that lack of qualifications in records management and archival studies remains a challenge in Africa.

\subsubsection{Formal qualifications in records management}

The respondents were asked if they had a formal qualifications in records management. Their responses are presented in Figure 5.

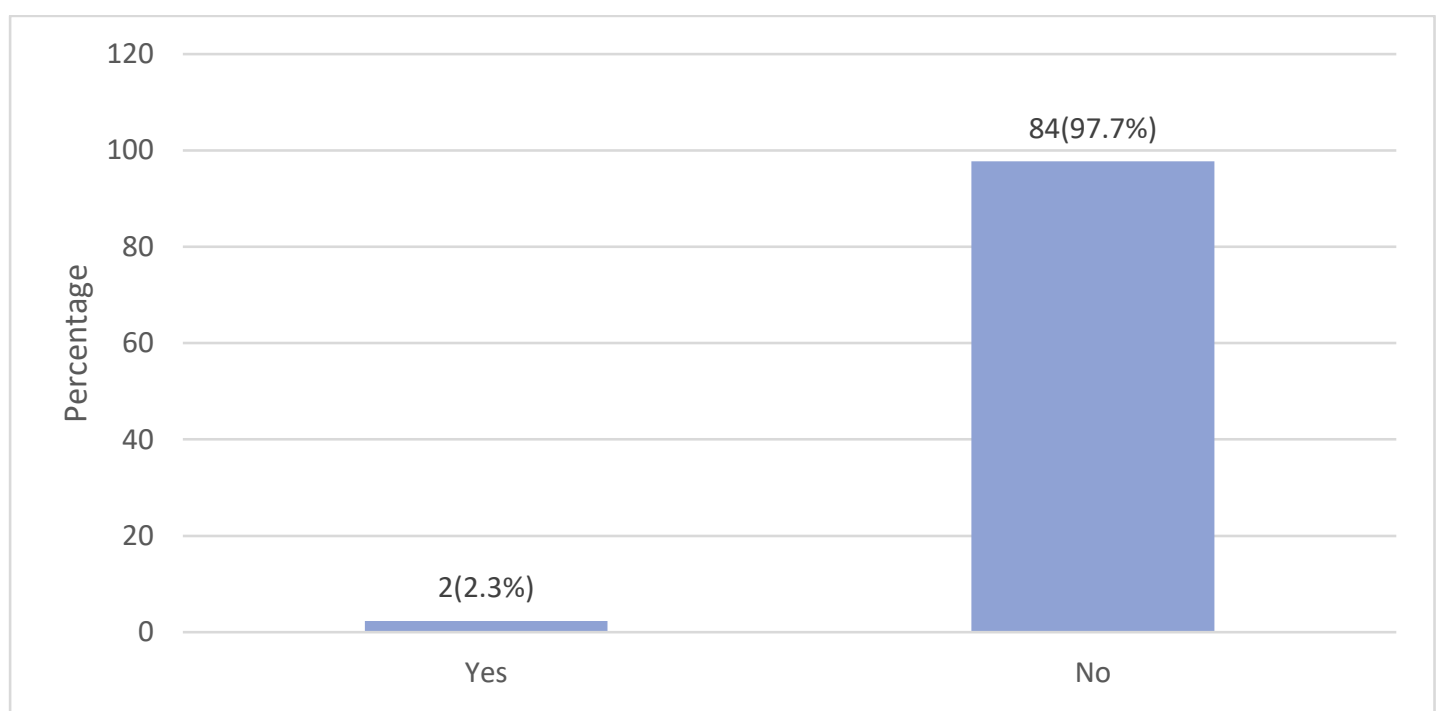

Figure 5: Formal qualification in records management $(n=86)$

Despite all the respondents working in registry offices, only two $(2.3 \%)$ had a formal qualification in records management. Marutha and Ngoepe (2018) asserts that records 
management officials who are not trained in records management become demoralised and uninterested in the work and merely do it for the sake of receiving a salary.

\subsubsection{In-house training in records management}

To improve records management practices, registry staff need in-house training in records management. Respondents were asked if they had received in-house training. The results are presented in Figure 6.

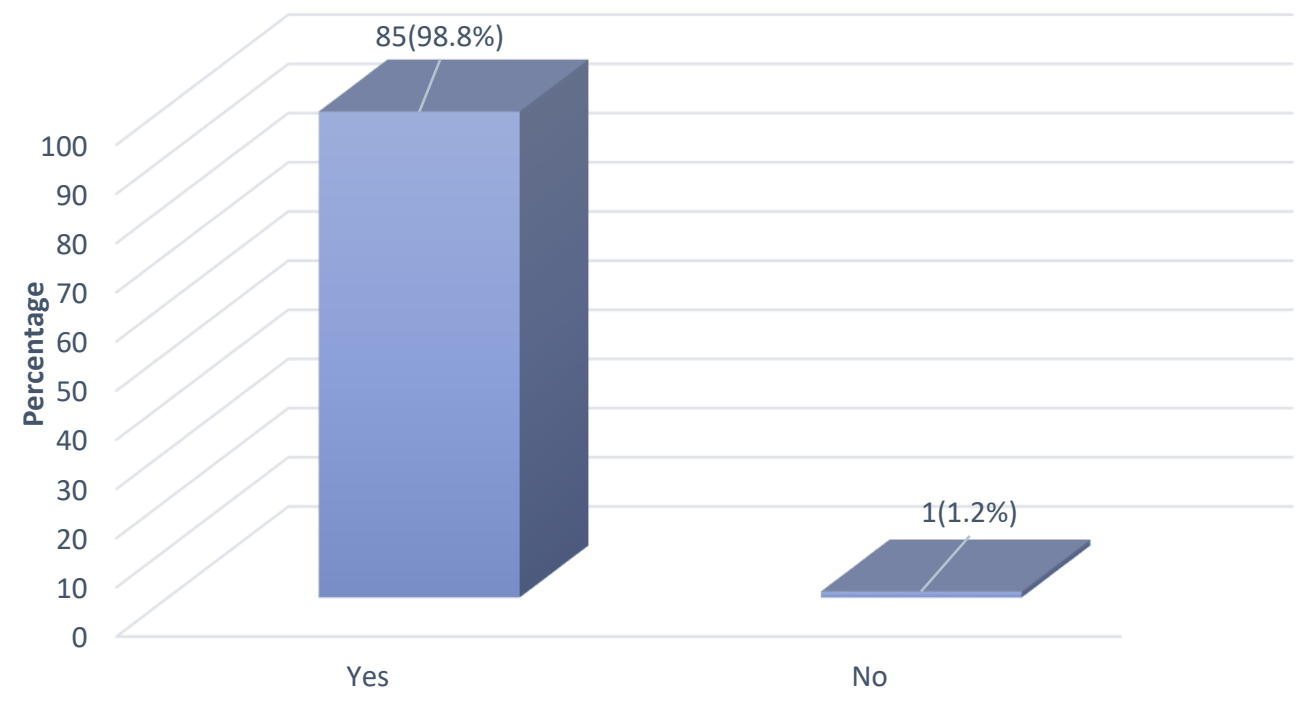

Figure 6: In-house training in records management $(\mathrm{n}=86)$

Except for one respondent, all 85 (98.9\%) indicated they had received in-house training in records management. In contrast, Marutha (2016) revealed that in Limpopo healthcare institutions, in-house records management training and workshops were received by only $56.7 \%$ of the respondents. However, the frequency of training in records management is an important consideration.

\subsubsection{Frequency of training in records management}

The respondents who indicated they received records management training were further asked to indicate how often they attended such training. The results are presented in Figure 7 below. 


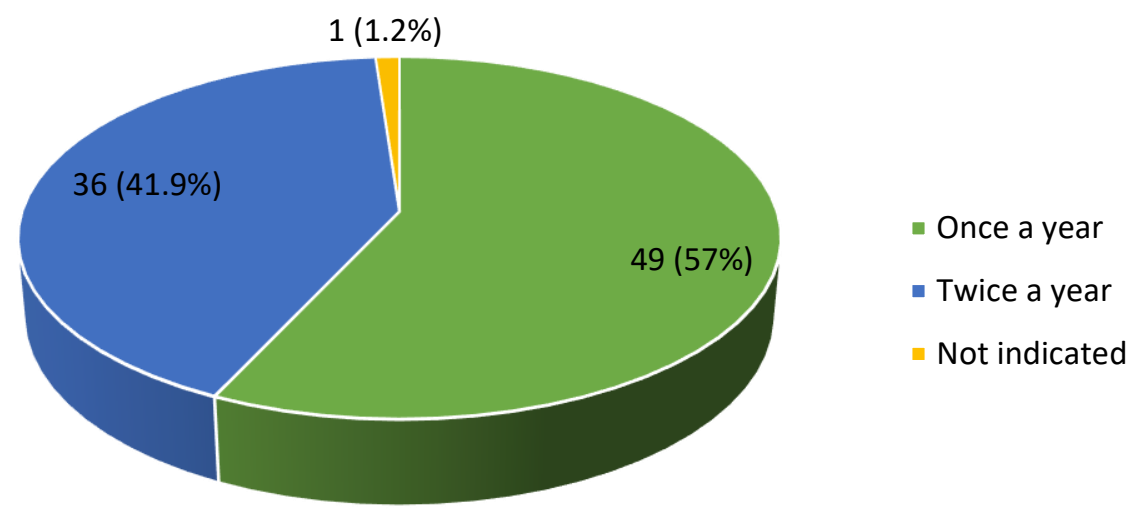

Figure 7: Frequency of training in records management $(n=86)$

The respondents indicated that they attend records management training once or twice a year. Most of the respondents (49: 57\%) attend training once a year, while 36 (41.9\%) did so twice a year. Thus, training was not offered by the selected municipalities more than twice a year. This suggests that the training of employees in records management was irregular. A similar conclusion was reached by Marutha and Ngoepe (2017), who revealed that the frequency of in-house training in records management in the Limpopo Department of Health was done irregularly.

\subsection{Challenges faced in managing records}

The respondents were requested to identify the main challenges they encountered in managing records in the municipality. This question was asked against the backdrop that records management practices can only be improved if one knows the challenges registry officials face. Twenty-one respondents $(24.4 \%)$ indicated staff shortages as a challenge in their municipalities, while 20 respondents $(23.3 \%)$ indicated their challenge as the lack of training in records management. In this regard, one of the registry staff had this to say:

"We were never trained in records management but are expected to perform our duties to our level abilities while they know very well that there are no qualifications in records management in South Africa except for those with junior degrees that can study postgraduate diplomas."

Seeing that over a fifth of the respondents indicated a lack of training suggests that the in-house training actually received (as in the findings above) was inadequate.

Twenty (23.3\%) respondents reported a lack of storage facilities in their municipalities as a challenge. In the words of one respondent: "We are struggling to deal with the large number of records received because there are no storage facilities and some of the records are even stored in boxes." 
Less mentioned challenges were as follows:

Eleven $(12.8 \%)$ respondents referred to the struggle of managing records due to the lack of support from the senior manager. In a similar vein, $10(11.6 \%)$ respondents said their managers do not see records management as a priority. One registry officer stated that "Records management is not seen as a priority by managers, as they dump people not needed in other departments in registry offices."

One (1.2\%) respondent raised the issue of political interference while another (1.2\%) said there was a lack of political support and pointed out that politicians request records but do not return them. When auditors come, the registry staff are expected to retrieve those records. One $(1.2 \%)$ respondent referred to the issue of unqualified staff as a serious challenge. The same respondent further reported that most people working in registry offices had been transferred from other vital departments like finance and accounts after being accused of corruption. As a result, they arrived without skills in records management.

It is clear from these results that the selected municipalities are facing numerous challenges in managing their records. In particular, training and a lack of appropriately qualified staff are arguably at the forefront of the challenges faced. However, the selected municipalities in Limpopo are not unique in terms of challenges in records management practices. Many countries in Africa have similar challenges (as outlined in the literature review). According to a study by Ngulube (2000), some of the challenges encountered by registry staff in managing records in the public sector in Zimbabwe included inadequate and inaccurate records, unauthorised access, mutilation, mishandling, denying access and use, compromising security, being used for criminal activities, being used to intimidate others, and unauthorised destruction and disclosure. Nevhutalu (2016) found that the inadequate training of registry staff in municipalities hindered the improvement of records management practices. A study by Asogwa (2012) concluded that corrupt leaders in Africa do not provide adequate funds for records management programmes. Asogwa (2012) added that some African leaders "distort public policies, public records, decision-making apparatuses, and sometimes go to any length to transfer experienced records managers in a bid to create opportunities for embezzlement." A study by Dewah (2018:75) on records management service in Zimbabwe also emphasised the funding issue, and concluded that:

the prevailing economic situation is presenting serious challenges to records management practices such that organisations' executives both public and private are allocating far below adequate financial resources towards records management activities.

Maseh (2015) states that most organisations in Africa are not coping with challenges related to the storage of records. Ngoepe and Keakopa (2011) note that the biggest challenge in records management in NARSSA was a lack of human resources. This observation is similar to the one by Masimba (2014) that one of the fundamental challenges facing records management in South Africa was a shortage of staff. Katuu and Ngoepe (2015:192), referring to education and training, assert that the absence of an "education and training programme is a key challenge to addressing the records management capacity deficit in SA." 


\section{Conclusion and recommendations}

The study aimed to assess the records management in municipalities with adverse audit opinions in the Limpopo Province, South Africa. It was found that these municipalities face numerous challenges associated with records management practices. The study contends that these challenges lead to municipalities receiving adverse audit opinions. The study further concludes that sound records management practices are important in improving audit opinions of municipalities. The lack of such practices is arguably one of the reasons why the 2020 Corruption Perceptions Index (CPI) presents a mostly gloomy picture for South Africa as reported by Transparency International (2020). Records management challenges identified in the study hamper municipalities in improving their audit opinions. Some of the reasons why municipalities are unable to improve their audit opinions include staff shortages, a lack of training in records management, a lack of storage facilities, a lack of support from the senior managers and management not viewing records management as a priority. Based on the study's findings, it is recommended that top management and political office-bearers of municipalities support records management practices in their municipalities by ensuring that adequate resources are allocated for records management programmes. In addition to improving records management practices, which is critical in the fight against corruption, government officials in South Africa should make funding available for this. The study recommends that an investigation be done on the possibility of more universities in South Africa introducing formal qualifications in records management. It is also recommended that only trained personnel in records management be employed to deal with records and those already employed without qualification(s) be supported in terms of training. Future studies should be conducted on the importance of education and training in records management and archival studies. Other studies can be conducted at the level of skills and knowledge of people working in records management and archival field.

\section{References}

Abuki, B.J. 2014. The role of records management in public service delivery in county governments in Kenya: a case study of Kisii County Government headquarters. Master's Thesis. Nairobi: University of Nairobi.

Adu, F. 2014. Assessment of records management practices among the administrative staff of the University of Education, Winneba-Kumasi (UEW-K) and Mampong (UEW-M) Campuses. Master's thesis, Kumasi, Kwame Nkrumah University of Science and Technology.

Asogwa, B.E. 2012. The challenge of managing electronic records in developing countries: implications for records managers in sub-Saharan Africa. Records Management Journal 22 (3): 198-211. Available at: https://www.emeraldinsight.com/doi/abs/10.1108/09565691211283156 (accessed 13 October 2018).

Auditor-General South Africa (AGSA). 2015. Implementing key internal controls to eliminate undesirable audit outcomes. Available at: https://www.agsa.co.za/portals/0/AG/Implementing_key_internal_controls_to_elimin ate_undesirable_audit_outcomes.pdf (accessed 15 March 2019).

Auditor-General South Africa (AGSA). 2016. Consolidated general report on the audit outcomes of local government 2015-16. Pretoria: Auditor-General. 
Babbie, E. \& Mouton, J. 2001. The practice of social research. Cape Town: Oxford University Press.

Bakare, A.A. \& Issa, A.O. 2014. An assessment of records management practice in selected local government councils in Ogun State, Nigeria. Journal of Information Science Theory and Practice 4(1): 49-64. http://www.jistap.org (accessed 22 July 2018).

Chaterera F. 2016. Managing public records in Zimbabwe: the road to good governance, accountability, transparency and effective service delivery. Journal of the South African Society of Archivists 27(49): 116-36. Available at: https://www.ajol.info/index.php/jsasa/article/view/138461/128027 (accessed 23 October 2018).

Chinyemba, A. \& Ngulube, P. 2005. Managing records at higher education institutions: a case study of the University of KwaZulu-Natal, Pietermaritzburg Campus. South African Journal of Information Management, 7(1).

Dewah, P. 2018. Records management consultancy service in Zimbabwe: the consultants' view. Journal of Librarianship and Information Science 50 (1): 68-76.

Erima, J.A. \& Wamukoya, J., 2012. Aligning records management and risk management with business processes: a case study of Moi University in Kenya. Journal of the South African Society of Archivists 45: 24-38.

International Records Management Trust (IRMT) in 2012. Managing records in a digital environment: the relationship to ICT/e-government and freedom of information strategy development. Available at: https://www.irmt.org/wp2/wp-content/uploads/2015/07/Right-to-InformationLessons-from-Nordic-Countries.pdf (accessed 25 August 2018).

Iwhiwhu, E.B. 2005. Management of records in Nigerian universities: Problems and prospects. The Electronic Library, 23(3): 345-355.

Kanzi, N. 2010. An investigation of the role of records management with specific reference to Amathole District Municipality. Master's dissertation, Port Elizabeth:,elson Mandela Metropolitan University.

Katekwe, P. \& Mutsagondo, S. 2018. Challenges and prospects of records maintenance in public departments: the case of the Midlands Province, Zimbabwe. Information Development 34(4): 397-407. https://doi.org/10.1177/0266666917712336 (accessed 25 August 2018).

Katuu, S. 2009. Archives and records management education and training: what can Africa learn from Europe and North America? Information Development 25(2): 133-145.

Katuu, S. \& Ngoepe, M. 2015. Managing digital records within SA's legislative and regulatory framework. In $3^{\text {rd }}$ International Conference on Cloud Security and Management ICCSM-2015, Tacoma, WA, University of Washington-Tacoma, p. 59.

Keakopa, S.M. 2007. The management of electronic records in Botswana, Namibia and SA: opportunities and challenges. PhD thesis, University College London, London.

Makhura, M.M. 2001. The role of electronic records management in a service organisation. Master's Thesis, University of Johannesburg, Johannesburg.

Marutha, N.S. 2016. A framework to embed medical records management into the healthcare service delivery in Limpopo Province of SA. PhD Thesis, University of South Africa, Pretoria.

Marutha, N.S. \& Ngoepe, M. 2017. The role of medical records in the provision of public healthcare services in the Limpopo Province of SA. South African Journal of Information Management 19(1): 1-8. 
Marutha, N.S. \& Ngoepe, M. 2018. Medical records management framework to support public healthcare services in Limpopo Province of SA. Records Management Journal 28(2): 187-203.

Maseh, E.J. 2015. Records management readiness for open government in the Kenyan judiciary. PhD thesis, University of KwaZulu-Natal, Pietermaritzburg.

Masimba, Y. 2014. The role of the National Archives and Records Service of SA in the young democracy. Master's thesis, University of the Witwatersrand, Johannesburg.

Mathebeni-Bokwe, P. 2015. Management of medical records for healthcare service delivery at the Victoria Public Hospital in the Eastern Cape Province: SA. PhD thesis, University of Fort Hare, Alice .

McLeod, J., Hare, C. \& Johare, R. 2004. Education and training for records management in the electronic environment - the (re)search for an appropriate model. Information Research 9(3): 179-184.

Mnjama, N. \& Wamukoya, J. 2007. E-government and records management: an assessment tool for e-records readiness in government. The Electronic Library, 25(3): 274-284.

Mosweu, O. \& Rakemane, D. 2020. The role of records management in ensuring good governance in Africa. Journal of the South African Society of Archivists, 53: 103-123.

National Archives and Records Service of SA. 2007. Records management policy manual, 1st ed. 1(4). Available at:

https://www.nationalarchives.gov.za/sites/default/files/RM\%20Policy\%20Manual_2.p df. (accessed 18 October 2016).

National Archives and Records Service of SA. 2006. Managing electronic records in government bodies: policies, principles and requirements, $2^{\text {nd }}$ ed. Pretoria: National Archives and Records Service of SA Vol. 1.3. Available at:

https://www.nationalarchives.gov.za/sites/default/files/Managing_electronic_records_ Policy_principles_and_Requirements_April_2006.pdf (accessed 12 November 2016).

Ndenje-Sichalwe, E. 2010. The significance of records management to fostering accountability in the public service reform programme of Tanzania. $\mathrm{PhD}$ thesis, University of KwaZulu-Natal, Pietermaritzburg.

Nengomasha, C.T. 2013. The past, present and future of records and archives management in sub-Saharan Africa. Journal of the South African Society of Archivists, 46: 2-2.

Nevhutalu, T. 2016. Role and trends of records management with specific reference to Vhembe District Municipality, Limpopo Province. Master's Thesis. University of Venda, Thohoyandou.

Ngoepe, M.S. 2012. Fostering a framework to embed the records management function into the auditing process in the SA public sector. PhD Thesis. University of South Africa, Pretoria.

Ngoepe, M. 2016. Records management models in the public sector in SA: is there a flicker of light at the end of the dark tunnel? Information Development 32 (3): 338-353.

Ngoepe, M. \& Keakopa, S. 2011. An assessment of the state of national archival and records systems in the ESARBICA region: a South Africa-Botswana comparison. Records Management Journal 21(2): 145-160. Available at: https://www.emeraldinsight.com/doi/abs/10.1108/0956569111115207 (accessed 05 August 2019).

Ngoepe, M.S. \& Ngulube, P. 2014. The need for records management in the auditing process in the public sector in SA. African Journal of Library, Archives and Information Science 24(2): 135-150. Available at: 
https://www.uir.unisa.ac.za/handle/10500/15412 (accessed 09 January 2020).

Ngoepe, M. \& Van Der Walt, T. 2009. A framework for a records management programme: lessons from the Department of Cooperative Governance and Traditional Affairs in SA. Mousaion 28(2): 82-106. Available at:

https://journals.co.za/content/mousaion/28/2/EJC79003 (accessed 7 September 2016).

Ngulube, P. 2000. Professionalism and ethics in records management in the public sector in Zimbabwe. Records Management Journal 10(3): 161-173. Available at: https://www.emeraldinsight.com/doi/abs/10.1108/EUM0000000007262 (accessed 15 June 2017).

Ngulube, P. 2003. Using the SECI knowledge management model and other tools to communicate and manage tacit indigenous knowledge. Innovation 27(1): 21-30.

Phiri, M.J. 2016. Managing university records and documents in the world of governance, audit and risk: case studies from SA and Malawi. PhD thesis, University of Glasgow, Glasgow.

Popoola, S.O. 2009. Organisational commitment of records management personnel in Nigerian private universities. Records Management Journal 19(3): 204-217.

SALGA. 2015. Status quo report on progress and challenges experienced by rural municipalities and demarcations problems. Johannesburg: SALGA. Available at: http://www.salga.org.za/Municipalities\%20AM.html (accessed 07 January 2019).

Schellnack-Kelly, I. 2013. The role of records management in governance-based evidence, service delivery and development in South African communities. $\mathrm{PhD}$ thesis, University of South Africa, Pretoria.

Shepherd, E. \& Yeo, G. 2003. Managing records: a handbook of principles and practice. London: Facet Publishing.

Transparency International. 2020. Corruption Perceptions Index 2020. Available at: https://www.transparency.org/cpi2018 (accessed 22 September 2020).

Venter, L. 2004. The impact of the Provincial Records Management Capacity Building Project on the roll-out of integrated document and records management solutions. Paper read at the Electronic Records Management Workshop in Cape Town, SA, 19 March.

Wamukoya, J. \& Mutula, S.M. 2005. Capacity-building requirements for e-records management: the case in East and Southern Africa. Records Management Journal 15(2): 71-79. Available at:

https://www.emeraldinsight.com/doi/abs/10.1108/09565690510614210 (accessed 29 September 2019).

Wamukoya, J. 2000. Records and archives as a basis for good government: implications and challenges for records managers and archivists in Africa. Records Management Journal 10(1): 23-33. Available at:

https://www.emeraldinsight.com/doi/abs/10.1108/09565690510614210 (accessed 19 March 2019).

World Bank. 2000. Managing records as the basis for effective service delivery and public accountability in development: an introduction to core principles for the staff of the New York World Bank and its Partners. Washington: World Bank.

Zwikael, O. 2008. Top management involvement in project management: exclusive support practices for different project scenarios. International Journal of Managing Projects in Business 1(3): 387-403. 